\title{
Research Paper Determinants of papaya market supply in Bilaspur district of Chhattisgarh
}

\author{
Bhekh Ram, A.K. Koshta and Chandrakant Sharma
}

See end of the paper for authors' affiliations

Correspondence to :

Bhekh Ram

Department of Agricultural

Economics, College of

Agriculture (IGKV), Raipur

(C.G.) India

Email : chadravanshi.

bhekh@gmail.com

Paper History :

Received : 31.12.2018;

Revised : 29.01.2019;

Accepted : 09.02.2019
ABSTRACT : The determinants in marketable supply of papaya reveals that land holding of farmer, educational level of house hold and experience in papaya production was found significant and contributed to marketable supply of papaya was5.13, 28.85 and 3.77, respectively. Distance to market have negative impact to marketable supply of papaya and found to be negatively significance $(-0.96)$. The family size has also been found negative effect to marketable supply of papaya and contributed to -3.18 , which was found to be non-significant.

KEY WORDS : Supply chain, Producers, Consumers, Marketing

How To Cite This PaPer : Ram, Bhekh, Koshta, A.K. and Sharma, Chandrakant (2019). Determinants of papaya market supply in Bilaspur district of Chhattisgarh. Internat. Res. J. Agric. Eco. \& Stat., 10 (1) : 75-79, DOI : 10.15740/HAS/IRJAES/10.1/75-79. Copyright@ 2019: Hind Agri-Horticultural Society. 